\title{
Propofol induces DNA damage in mouse leukemic monocyte macrophage RAW264.7 cells
}

\author{
KING-CHUEN WU ${ }^{1}$, SU-TSO YANG ${ }^{2,3}$, SHU-CHUN HSU $^{4}$, JO-HUA CHIANG $^{5}$, TE-CHUN HSIA ${ }^{6}$, \\ JAI-SING YANG $^{7}$, KUO-CHING LIU ${ }^{8}$, RICK SAI-CHUEN WU ${ }^{* *}$ and JING-GUNG CHUNG ${ }^{4,10^{*}}$
}

\begin{abstract}
${ }^{1}$ Department of Anesthesiology, E-DA Hospital/I-Shou University, Kaohsiung 824; ${ }^{2}$ Department of Radiology, China Medical University Hospital, Taichung 404; ${ }^{3}$ School of Chinese Medicine, China Medical University, Taichung 404; ${ }^{4}$ Department of Biological Science and Technology, China Medical University, Taichung 404; ${ }^{5}$ Department of Life Sciences, National Chung Hsing University, Taichung 402; ${ }^{6}$ Department of Internal Medicine, China Medical University Hospital, Taichung 404; ${ }^{7}$ Department of Pharmacology, China Medical University, Taichung; ${ }^{8}$ Department of Medical Laboratory Science and Biotechnology, China Medical University, Taichung 404; ${ }^{9}$ Department of Anesthesiology, China Medical University Hospital, Taichung 404; ${ }^{10}$ Department of Biotechnology, Asia University, Taichung 413, Taiwan, R.O.C.
\end{abstract}

Received May 28, 2013; Accepted August 7, 2013

DOI: $10.3892 / o r .2013 .2722$

\begin{abstract}
Propofol is one of the most widely clinically used intravenous anesthetic, and it induces apoptosis in human and murine leukemia cell lines. Yet, whether propofol causes DNA damage and affects the mRNA expression of repairassociated genes in cancer cells remains undetermined. In the present study, we investigated the effects of propofol on DNA damage and associated mRNA gene expression in RAW264.7 cells. Comet assay and DNA gel electrophoresis were used to evaluate DNA damage in RAW264.7 cells and propofolinhibited cell growth in vitro. The results revealed a longer DNA tail and DNA fragmentation. Real-time PCR assay was used to examine mRNA gene expression of DNA damage and DNA repair-associated genes. Following exposure to propofol for $48 \mathrm{~h}$, a decrease in the mRNA expression of DNA-PK, BRCA1, MGMT and p53 was noted in the RAW264.7 cells. Results from the western blotting indicated that p53, MGMT, 14-3-3- $\sigma$, BRCA1 and MDC1 proteins were decreased while p-p53 and p-H2A.X(S140) were increased in the RAW264.7 cells following exposure to propofol. In conclusion, exposure
\end{abstract}

Correspondence to: Dr Jing-Gung Chung, Department of Biological Science and Technology, China Medical University, 91 Hsueh-Shih Road, Taichung 40402, Taiwan, R.O.C.

E-mail: jgchung@mail.cmu.edu.tw

Dr Rick Sai-Chuen Wu, Department of Anesthesiology, China Medical University Hospital, 2 Yude Road, Taichung 40447, Taiwan, R.O.C.

E-mail: rickwuu@mail.cmuh.org.tw

*Contributed equally

Key words: propofol, DNA damage, comet assay, DNA repair, murine leukemia RAW 264.7 cells to propofol caused DNA damage and inhibited mRNA expression and protein levels of repair-associated genes in RAW264.7 cells.

\section{Introduction}

Hematological malignancies are a form of cancer that includes leukemia and lymphoma (1). Leukemia is one of the cancers that causes extensive mortality in the human population. It is known that leukemia starts in hematopoietic elements primarily in the bone marrow, the soft tissue inside most bones, then progresses to the blood, lymph nodes or other organs leading to serious health problems. In Taiwan, the 2009 Report of the Department of Health, R.O.C. (Taiwan) indicated that $\sim 4$ out of 100,000 individuals die each year of leukemia, and it is the 11th most common malignancy (2). At present, the treatment of patients with leukemia includes bone marrow transplant, radiotherapy and chemotherapy $(3,4)$. However, these treatments are still unsatisfactory, and the exact mechanisms involved in leukemia are unclear.

Propofol (2,6-diisopropylphenol), is commonly used as an intravenous sedative-hypnotic (anesthetic). It has analgesic effects in inflammation-induced pain and facilitated pain (5) and has been clinically used for patients in rapid emergence after cessation of infusion (6). Propofol contains cardiac protection during ischemia-reperfusion (7-9), and it has been reported that propofol upregulates AQP1 expression (10) and inhibits nitric oxide synthase (11) in endotoxemia-mediated lung injury. However, animal studies suggest that propofol protects against endotoxemia-induced lung and kidney injuries $(12,13)$.

A previous study found that propofol induces apoptosis, which is dependent on the mechanism that activates both the cell surface death receptor pathway and the mitochondrial pathway. It was also found that propofol may trigger neurodegeneration in neurons during development and its derivative may affect neuronal injury, including apoptotic cell death (14). 
It was also demonstrated that propofol inhibited the decarboxylase activity in three-dimensional primary cell cultures of fetal rat telencephalon (15). Recently, we found that propofol induced apoptosis in murine leukemia RAW264.7 cells in vitro through altered levels of apoptosis-associated proteins resulting in induction of apoptotic gene expression and inhibition of cell growth (13).

It was reported that the neuro-degeneration in age-related diseases, cerebral ischemia and brain trauma is associated with DNA damage (16), and if agents can induce DNA damage in cells, this may lead to cell mutations and to the development of malignancy. Although numerous studies indicate that propofol induces cell death, no information has addressed the effects of propofol-induced DNA damage in murine leukemia cells. Therefore, in the present study, we investigated the effects of propofol on DNA damage and expression (mRNA) of DNA repair-associated genes in murine leukemia RAW264.7 cells. The results revealed that propofol induced DNA damage and inhibited the expression of DNA damage and repair-associated genes in RAW264.7 cells in vitro.

\section{Materials and methods}

Chemicals and reagents. Propofol was obtained from B. Braun Melsungen AG (Schwarzenberger Weg, Melsungen, Germany). A stock solution of propofol was prepared in phosphate-buffered saline (PBS), and an equal volume of PBS $(0.1 \%)$ was added to the controls. RPMI-1640 medium, fetal bovine serum (FBS), L-glutamine and penicillin-streptomycin were obtained from Gibco ${ }^{\circledR} /$ Invitrogen Life Technologies (Grand Island, NY, USA).

Cell culture and treatment. The RAW264.7 murine leukemia cell line was obtained from the Food Industry Research and Development Institute (Hsinchu, Taiwan). The RAW264.7 cells were maintained in RPMI-1640 medium with $2 \mathrm{mM}$ L-glutamine, supplemented with $10 \%$ heat-inactivated FBS and $100 \mathrm{U} / \mathrm{ml}$ penicillin and $100 \mu \mathrm{g} / \mathrm{ml}$ streptomycin, and incubated at $5 \% \mathrm{CO}_{2}$ and $37^{\circ} \mathrm{C}$ and $90 \%$ relative humidity. Propofol was diluted in sterile PBS before addition to the culture. The cells which were treated with PBS served as the control and were assigned to have $100 \%$ survival.

Cell viability analysis. Approximately $2 \times 10^{5}$ cells/well of RAW264.7 cells in 12-well plates were maintained for $24 \mathrm{~h}$ in an incubator. Cells in each well were incubated with propofol at the final concentrations of $0,25,50,100$ and $200 \mu \mathrm{g} / \mathrm{ml}$, vehicle $(1 \mu \mathrm{l} \mathrm{PBS})$ or $0.1 \%$ hydrogen peroxide $\left(\mathrm{H}_{2} \mathrm{O}_{2}\right.$, positive control) for $48 \mathrm{~h}$. Cells were also treated with $100 \mu \mathrm{g} /$ $\mathrm{ml}$ propofol for 24, 48 and $72 \mathrm{~h}$. Cells from each treatment group were stained with $4 \mu \mathrm{g} / \mathrm{ml}$ propidium iodide (PI) (Sigma-Aldrich Corp., St. Louis, MO, USA) and analyzed by FACSCalibur flow cytometry (Becton-Dickinson, San Jose, CA, USA). Cell viability was calculated as previously described $(13,17)$.

Measurement of DNA damage by comet assay. RAW264.7 cells $\left(2 \times 10^{5} /\right.$ well) in 12 -well plates were incubated with 0,25 , $50,100$ and $200 \mu \mathrm{g} / \mathrm{ml}$ of propofol, vehicle (1 $\mu \mathrm{l} \mathrm{PBS})$ or $0.1 \%$ $\mathrm{H}_{2} \mathrm{O}_{2}$ for $48 \mathrm{~h}$, or cells were exposed to $100 \mu \mathrm{g} / \mathrm{ml}$ propofol for
Table I. Primer sequences used in the real-time PCR.

\begin{tabular}{ll}
\hline Primer name & \multicolumn{1}{c}{ Primer sequence } \\
\hline$D N A-P K-\mathrm{F}$ & TTCAAGACTTCAACCGCTTT \\
$D N A-P K-\mathrm{R}$ & TGCGGCTGGGTCAAGTGT \\
$B R C A l-\mathrm{F}$ & TTGAAGTCAAAGGAGACGTTG \\
$B R C A l-\mathrm{R}$ & TCTTTGGGCATGTTGGTGAA \\
$M G M T-\mathrm{F}$ & TCCCTTGCCTGCTCTCCAT \\
$M G M T-\mathrm{R}$ & AACCATTTCTCCGAATTTCACAA \\
$p 53-\mathrm{F}$ & GGGTTAGTTTACAATCAGCCACATT \\
$p 53-\mathrm{R}$ & GGGCCTTGAAGTTAGAGAAAATTCA \\
$G A P D H-\mathrm{F}$ & GGTGGACCTCATGGCCTACA \\
$G A P D H-\mathrm{R}$ & CAGCAACTGAGGGCCTCTCT
\end{tabular}

$\mathrm{F}$, forward; R, reverse. DNA-PK, DNA-dependent serine/threonine protein kinase; BRCA1, breast cancer gene 1; MGMT, $O^{6}$-methylguanine-DNA methyltransferase; GAPDH, glyceraldehydes-3-phosphate dehydrogenase.

24, 48 and $72 \mathrm{~h}$ in RPMI-1640 medium and grown at $37^{\circ} \mathrm{C}$ in $5 \% \mathrm{CO}_{2}$ and $95 \%$ air. Cells from each treatment group were harvested by centrifugation for examination of DNA damage using the comet assay as previously described $(18,19)$. The TriTek CometScore ${ }^{\mathrm{TM}}$ software image analysis system (TriTek Corp., Sumerduck, VA, USA) was used to calculate and quantify the comet tail length as previously described $(18,19)$.

Evaluation of DNA fragmentation by DNA gel electrophoresis. RAW264.7 cells at a density of $2 \times 10^{6}$ cells/well in 6-well plates were incubated with propofol $(25,50,100$ and $200 \mu \mathrm{g} /$ $\mathrm{ml})$ or vehicle $(1 \mu \mathrm{l} \mathrm{PBS})$ for $48 \mathrm{~h}$ at $37^{\circ} \mathrm{C}$ in $5 \% \mathrm{CO}_{2}$ and $95 \%$ air. Cells from each treatment group were individually isolated, and then DNA was extract using a DNA isolation kit (Genemark Technology Co., Ltd., Tainan, Taiwan) $(20,21)$. DNA electrophoresis was carried out on $1.5 \%$ agarose gel in Tris/boric acid buffer at $15 \mathrm{~V}$ for $2 \mathrm{~h}$, and DNA was stained with ethidium bromide (EtBr; Sigma-Aldrich Corp.) and then examined and photographed under UV light box as previously described (18-20).

Analysis of gene expression by real-time PCR assay. RAW264.7 cells at a density of $2 \times 10^{6} /$ well in 6-well plates were incubated with $100 \mu \mathrm{g} / \mathrm{ml}$ propofol or without for $48 \mathrm{~h}$. The total RNA from each sample was extracted using the Qiagen RNeasy Mini kit (Qiagen, Inc., Valencia, CA, USA) as previously described $(18,20)$. Briefly, the High Capacity cDNA reverse transcription kit was used for RNA samples which were reverse-transcribed for $30 \mathrm{~min}$ at $42^{\circ} \mathrm{C}$ according to the standard protocol of the supplier (Applied Biosystems, Carlsbad, CA, USA). The quantitative PCR from each sample was performed under the following conditions: $2 \mathrm{~min}$ at $50^{\circ} \mathrm{C}$, $10 \mathrm{~min}$ at $95^{\circ} \mathrm{C}$, and 40 cycles of $15 \mathrm{sec}$ at $95^{\circ} \mathrm{C}, 1 \mathrm{~min}$ at $60^{\circ} \mathrm{C}$ using $1 \mu \mathrm{l}$ of the cDNA reverse-transcribed as described above, 2X SYBR-Green PCR Master Mix (Applied Biosystems) and $200 \mathrm{nM}$ of forward and reverse primers as shown in Table I. 

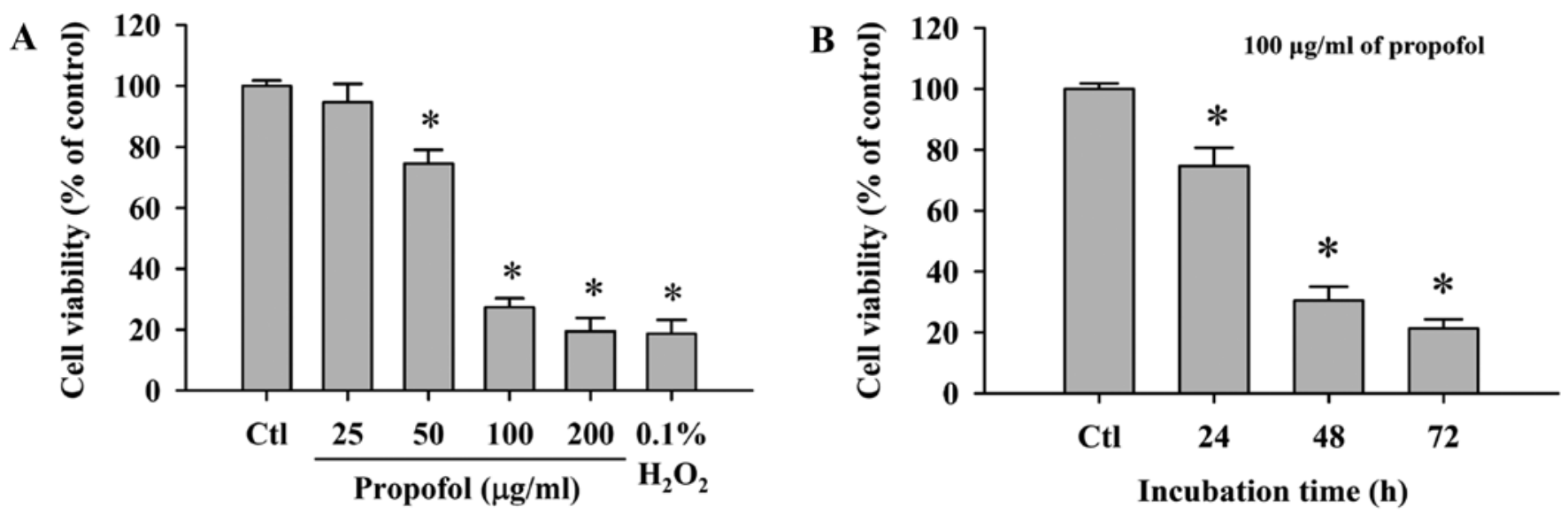

Figure 1. Propofol decreases the percentage of viable murine leukemia RAW264.7 cells. (A) Cells at a density of $2 \times 10^{5} /$ well were placed in 12 -well plates and then incubated with propofol at final concentrations of 25, 50,100 and $200 \mu \mathrm{g} / \mathrm{ml}$, vehicle ( $1 \mu \mathrm{l} \mathrm{PBS}$ ) or $0.1 \% \mathrm{H}_{2} \mathrm{O}_{2}$ (positive control) for $48 \mathrm{~h}$ or (B) cells were treated with $100 \mu \mathrm{g} / \mathrm{ml}$ propofol for 24, 48 and $72 \mathrm{~h}$. Cells from each treatment group were analyzed by flow cytometry as described in Materials and methods. ${ }^{*} \mathrm{P}<0.05$ was considered to indicate a significant difference between the experimental and control groups.

Finally, the DNA sequence was evaluated using the Primer Express software and each assay was run on an Applied Biosystems 7300 real-time PCR system in triplicates to ensure reproducibility. Expression fold-changes were derived using the comparative $\mathrm{C}_{\mathrm{T}}$ method (22).

Analysis of protein expression by Western blot assay. RAW264.7 cells $\left(2 \times 10^{6} /\right.$ well) were placed in a 6 -well plate and then propofol was added to the cells at final concentrations of 2.5, 5 and $10 \mu \mathrm{M}$, while DMSO (solvent) alone was added to the wells as a vehicle control. Cells were incubated with propofol in medium with $10 \% \mathrm{FBS}$ at $37^{\circ} \mathrm{C}$ for 0,6 , 12 and $24 \mathrm{~h}$. Cells were harvested and resuspended in lysis buffer [ice-cold $50 \mathrm{mM}$ potassium phosphate buffer $(\mathrm{pH} 7.4)$ containing $2 \mathrm{mM}$ EDTA and $0.1 \%$ Triton $\mathrm{X}-100]$. The collected cells were sonicated and centrifugated at $13,000 \mathrm{x} \mathrm{g}$ for $20 \mathrm{~min}$ at $4^{\circ} \mathrm{C}$ to remove cell debris, and the supernatant was collected for determination of total protein concentration using a Bio-Rad protein assay kit (Bio-Rad Laboratories, Hercules, CA, USA) with bovine serum albumin (BSA) as the standard. SDS gel electrophoresis and western blotting were performed as previously described $(22,23)$ for determining the effects of propofol on the protein levels of p53, p-p53, MGMT, p-H2A.X(S140), 14-3-3-б, BRCA1 and MDC1.

Statistical analysis. All data are presented as the means \pm SD, and the Student's t-test was used to analyze differences between the propofol-treated and untreated (control) groups. All statistical analyses were performed, and $\mathrm{P}<0.05$ was considered to indicate a statistically significant result.

\section{Results}

Effect of propofol on the viability of RAW264.7 cells. Cells were treated with $0,25,50,100$ and $200 \mu \mathrm{g} / \mathrm{ml}$ of propofol for $48 \mathrm{~h}$ or treated with $100 \mu \mathrm{g} / \mathrm{ml}$ propofol for $0,24,48$ and $72 \mathrm{~h}$. All cells from each treatment group were collected and then flow cytometric assay was used to evaluate the percentage of viable RAW264.7 cells. Propofol decreased the percentage of viable cells when compared to the control in a dose-dependent (Fig. 1A) and time-dependent manner (Fig. 1B).

Propofol induces DNA damage in RAW264.7 cells. We investigated whether propofol induces DNA damage in RAW264.7 cells in vitro. The comet assay was selected for determining DNA damage. The results indicated that propofol induced DNA damage in RAW264.7 cells. Higher concentrations of propofol led to a longer DNA migration smear (comet tail), and these effects occurred in a dose- (Fig. 2A and B) and time-dependent manner (Fig. 2C and D). As shown in Fig. 2A, $0.1 \% \mathrm{H}_{2} \mathrm{O}_{2}$ induced the occurrence of a comet tail, and $\mathrm{H}_{2} \mathrm{O}_{2}$ is well documented as a highly reactive oxygen species and it has been used as a positive control for numerous studies involving agent-induced DNA damage.

Propofol induces DNA fragmentation in RAW264.7 cells. As shown in Fig. 2, propofol induced DNA damage in RAW264.7 cells, and therefore, DNA gel electrophoresis was used to investigate whether propofol causes DNA fragmentation in RAW264.7 cells. Cells were treated with various concentrations of propofol for $48 \mathrm{~h}$, and then DNA was isolated from each treatment group. DNA fragmentation was assessed by DNA gel electrophoresis. As shown in Fig. 3, propofol induced DNA fragmentation in RAW264.7 cells.

Effects of propofol on expression of DNA damage and repairassociated genes in RAW264.7 cells. Based on the above results from the comet assay and DNA gel electrophoresis, we found that propofol induced DNA damage and fragmentation in RAW264.7 cells. Thus, we further investigated the effects of propofol on the expression of DNA damage and repairassociated genes in RAW264.7 cells. mRNA expression of all examined genes associated with DNA damage and repair including DNA-PK, BRCA1, MGMT and p53 was decreased following $48 \mathrm{~h}$ of exposure to propofol (Fig. 4).

Effects of propofol on the expression of DNA damage and repair-associated proteins in RAW264.7 cells. To further 
A
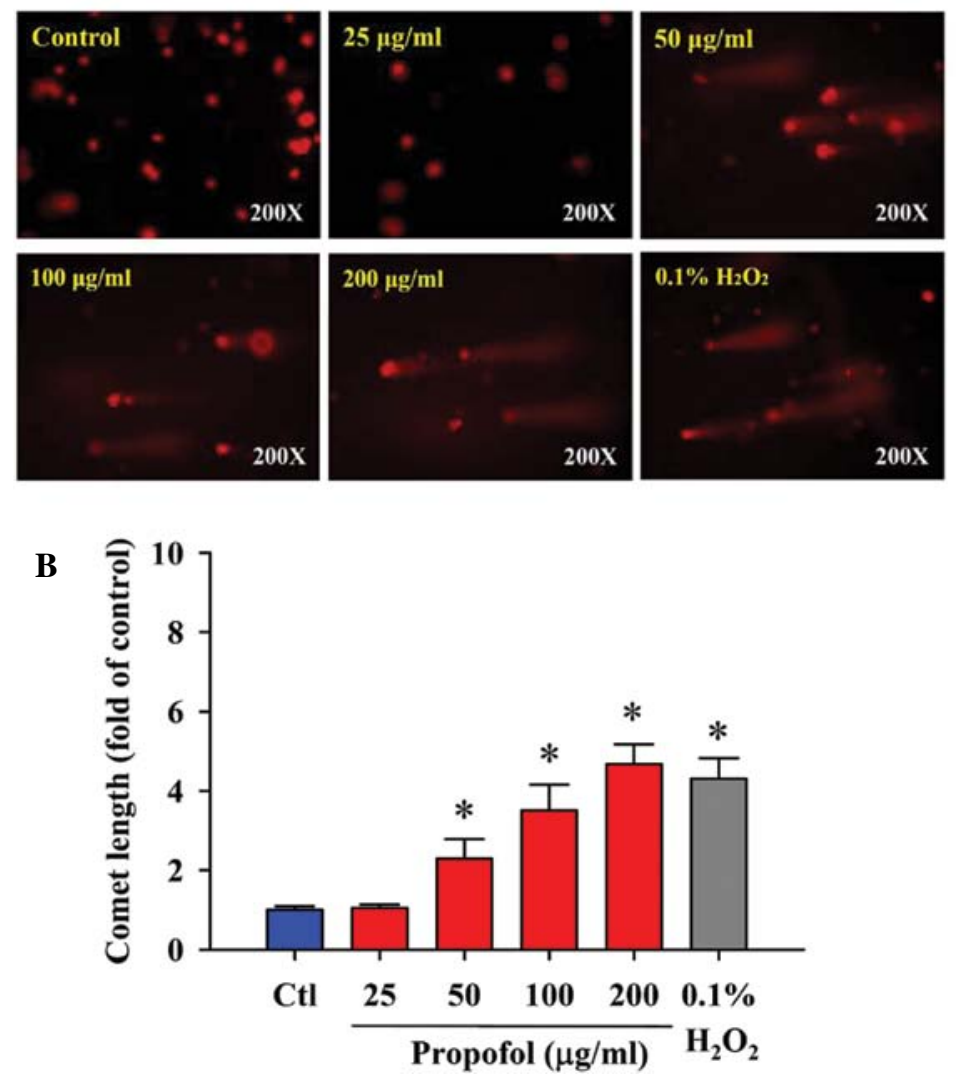

C

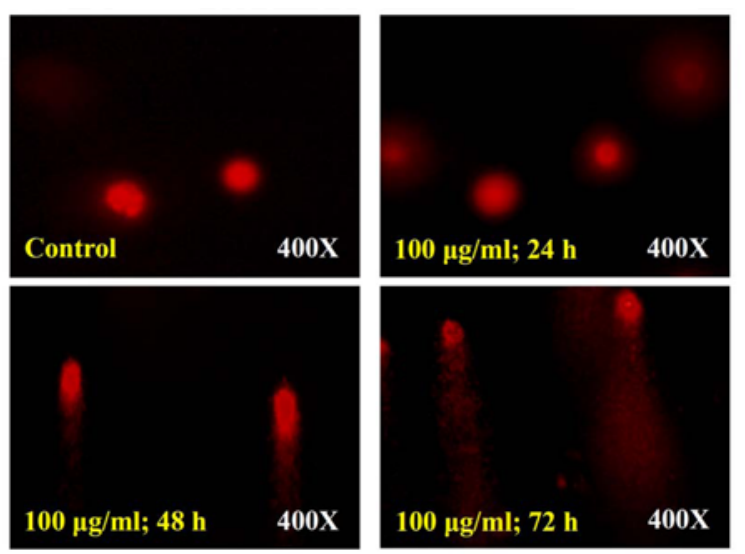

D

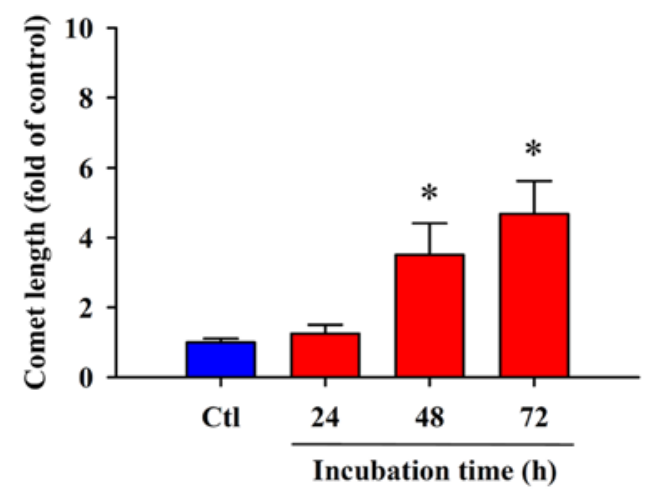

Figure 2. Propofol-induced DNA damage in RAW264.7 cells was determined by comet assay. Cells at a density of 2x105/well in 12 -well plates were incubated with propofol at final concentrations of $25,50,100$ and $200 \mu \mathrm{g} / \mathrm{ml}$, vehicle $\left(1 \mu 1 \mathrm{PBS}\right.$ ) or $0.1 \% \mathrm{H}_{2} \mathrm{O}_{2}$ (positive control) for $48 \mathrm{~h}$; or cells were treated with $100 \mu \mathrm{g} /$ $\mathrm{ml}$ propofol for 24,48 and $72 \mathrm{~h}$. DNA damage was determined by comet assay as described in Materials and methods. Representative images of the comet assay for (A) dose- and (C) time-dependent effects; (B and D) comet lengths (folds of control). Comet tail shows DNA damage. "P<0.05 was considered to indicate a significant difference compared to the control sample.

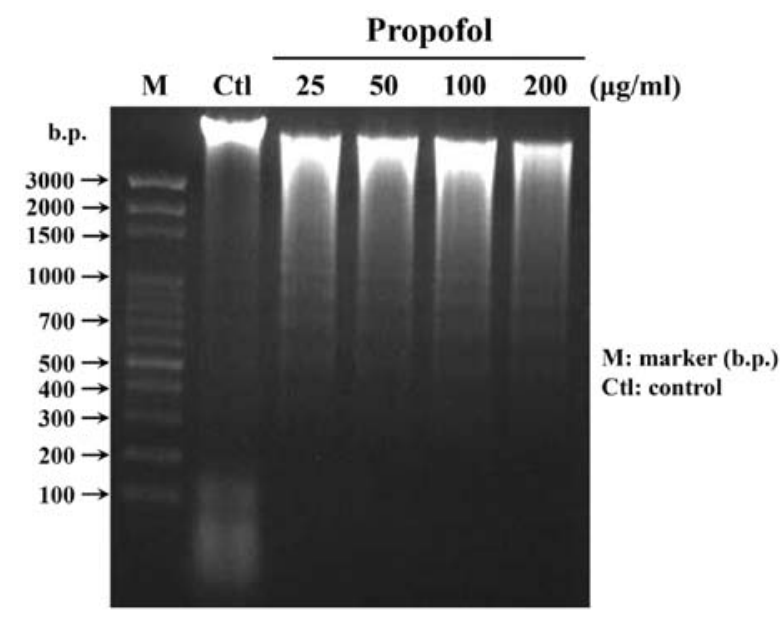

Figure 3. Propofol-induced DNA fragmentation in RAW264.7 cells as determined by DNA gel electrophoresis. Cells at a density of $2 \times 10^{6} /$ well in 6-well plates were incubated with propofol at final concentrations of 25, 50, 100 and $200 \mu \mathrm{g} / \mathrm{ml}$ for $48 \mathrm{~h}$. Cells were collected, and DNA was isolated from the cells of each treatment group for gel electrophoresis as described in Materials and methods.

confirm whether propofol inhibits DNA repair gene expression and whether it also affects the associated protein expression, RAW264.7 cells were treated with propofol and then harvested

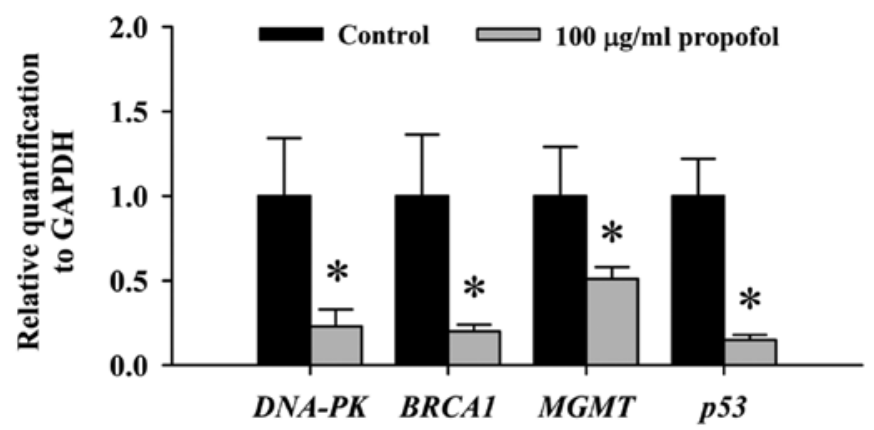

Figure 4. Propofol alters mRNA expression of DNA damage and repairassociated genes in RAW264.7 cells as determined by real-time PCR. Total RNA was extracted from the RAW264.7 cells following treatment with or without $100 \mu \mathrm{g} / \mathrm{ml}$ propofol for $24 \mathrm{~h}$. RNA samples were reverse-transcribed to cDNA and real-time PCR was conducted as described in Materials and methods. The ratios of DNA-PK, BRCA1, MGMT and p53 mRNA/GAPDH are presented in the bars of the histogram. Data represents mean $\pm \mathrm{SD}$ of three experiments. ${ }^{*} \mathrm{P}<0.05$ was considered to indicate a significant difference when compared to the control.

for western blotting. As shown in Fig. 5, levels of p53, MGMT, 14-3-3- $\sigma$, BRCA1 and MDC1 proteins were decreased while p-p53 and p-H2A.X(S140) were increased in the RAW264.7 cells following exposure to propofol. 
A

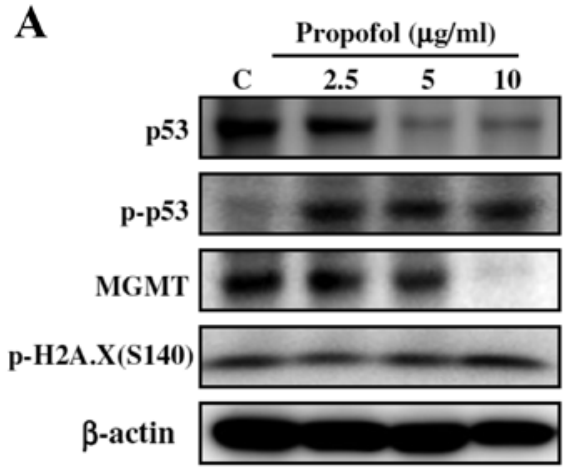

B

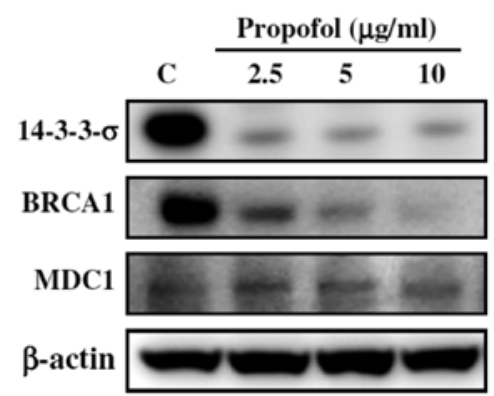

Figure 5. Propofol affects levels of DNA damage and repair-associated proteins in RAW264.7 cells. RAW264.7 cells were treated with propofol $(0,2.5$, 5 and $10 \mu \mathrm{g} / \mathrm{ml}$ ) and were then harvested for western blotting as described in Materials and methods. The protein levels of p53, p-p53, MGMT and p-H2A.X(S140) (A), 14-3-3- $\sigma$, BRCA1 and MDC1 (B) were examined from cells after exposure to propofol. The blots shown are representative from three independent experiments.

\section{Discussion}

Cytotoxic drugs and radiation are well-known DNA-damaging agents commonly used for cancer therapy and associated with the development of therapy-related myeloid neoplasms (23). Based on reports from other investigators, propofol was found to induce cytotoxic effects on human leukemia HL-60 cells via induction of apoptosis (24). Our previous study found that propofol induced apoptosis in murine leukemia RAW264.7 cells (13). However, there is no available information that has addressed propofol-induced DNA damage in murine leukemia cells. In the present study, we confirmed that propofol has cytotoxic effects on RAW264.7 cells, and we also demonstrated that propofol induced DNA damage (Fig. 2A and C) and DNA fragmentation (Fig. 3) and these effects were dose-dependent, and associated with loss of cell viability (Fig. 1). Furthermore, western blotting assay was used to examine the expression of DNA repair-associated protein. The results indicated that levels of p53, MGMT, 14-3-3-б, BRCA1 and MDC1 proteins were decreased while p-p53 and p-H2A.X(S140) were increased in RAW264.7 cells following exposure to propofol. In the present study, the dose of propofol for inducing DNA damage was $25 \mu \mathrm{g} /$ $\mathrm{ml}$ which is lower than that of other reports showing the blood concentration of propofol to be $<25 \mu \mathrm{g} / \mathrm{ml}$ during and after anesthesia (24). Possibly the in vitro studies used culture plates, and the propofol directly affected the cells.

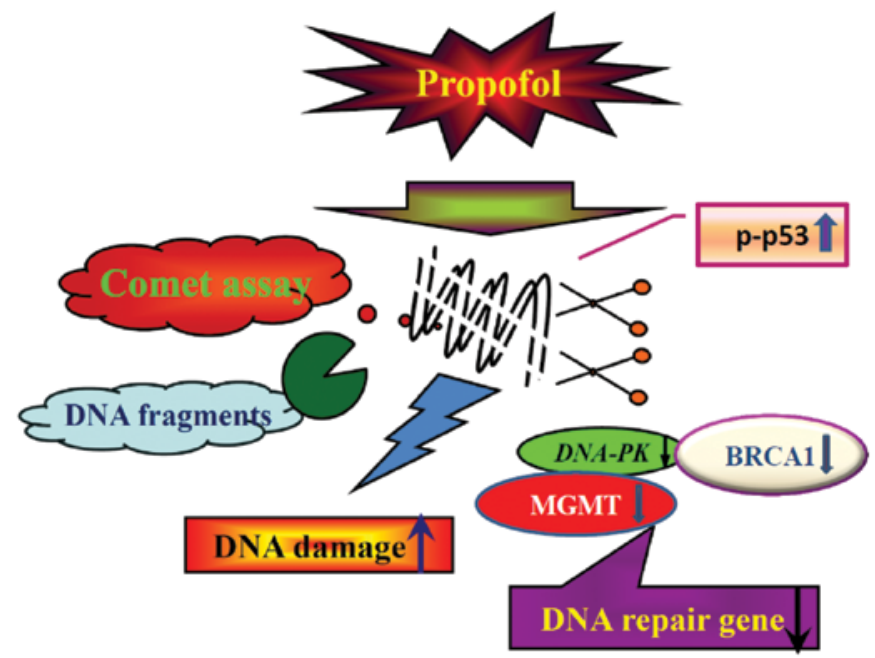

Figure 6. Possible signaling pathways involved in the inhibition of expression of DNA damage and repair-associated genes in murine leukemia RAW264.7 cells by propofol.

In the present study, the comet assay revealed that propofol induced nuclear DNA damage. It has been reported that various types of DNA damage are associated with cancer development, and therefore, mutations resulting from DNA damage are considered to be a hallmark of cancer (25). Thus, whether or not propofol is a carcinogen requires further investigation. However, numerous studies have used the comet assay to examine whether agents induce DNA damage based on its high sensitive technique for DNA damage assessment (26-28). Other investigators also showed that the comet assay can measure the strand-break formation during the process of excision repair of DNA $(29,30)$.

In our previous study, we found that propofol-induced cell death was mediated through induction of apoptosis in RAW264.7 cells, as determined by DAPI staining (13). In the present study, we also confirmed that propofol caused DNA fragmentation as determined by DNA gel electrophoresis (Fig. 3). Our previous study showed that propofol induced apoptosis through the activation of caspase-3 in RAW264.7 cells, not via reactive oxygen species (ROS) (13). This is in agreement with other reports which found that propofol was capable of scavenging hydrogen peroxide $\left(\mathrm{H}_{2} \mathrm{O}_{2}\right)(31)$. Thus, we suggest that propofol-induced DNA damage occurs independently of ROS production. Further studies are needed to establish the role of the interaction of propofol with DNA in cancer cells.

Agent-induced DNA damage can result in the loss of DNA repair capacity and accumulation of DNA damage. It was reported that agent-induced DNA damage can be reduced by DNA repair system through eliminating DNA lesions (32-34). In the present study, propofol-induced DNA damage in RAW264.7 cells is not clear. Therefore, to our knowledge this is the first report on propofol-induced DNA damage in murine leukemia cells. The mechanism involved in the DNA damage observed in the present study remains to be determined.

The results from real-time PCR revealed that propofol inhibited expression of DNA repair-associated genes 
including DNA-PK, BRCA-1, MGMT and p53 (Fig. 4) dosedependently in the RAW264.7 cells. Importantly, it has been reported that if agents cause DNA damage in checkpoints of the cell cycle, then there are signal transduction pathways involved in the cell cycle and cellular responses to DNA damage for maintaining genomic integrity (35-37). In human breast and ovarian cancer, it was reported that BRCA1 (tumor suppressor) plays critical roles in DNA repair, cell cycle checkpoint control and maintenance of genomic stability (38). DNA-PK plays an important role in DNA damage repair (39). Furthermore, MGMT reduces cytotoxicity of therapeutic or environmental alkylating agents $(40,41)$. Another report demonstrated that anesthesia with propofol did not directly influence the expression of the DNA repair genes hOGG1 and XRCC1 in blood cells (42). Herein, we demonstrated that propofol inhibited expression of several of the DNA repairassociated genes including DNA-PK, BRCA-1 and MGMT in RAW264.7 cells. Furthermore, western blotting showed that propofol inhibited levels of DNA repair-associated proteins such as MGMT, 14-3-3- $\sigma$, BRCA1 and MDC1, and DNA damage-associated 553 proteins. Notably, propofol promoted p53 phosphorylation.

Our proposed flow chart for propofol-induced DNA damage in murine leukemia RAW264.7 cells is illustrated in Fig. 6, which shows that propofol induces DNA damage followed by the inhibition of expression (mRNA) of DNA repair-associated genes including DNA-PK, BRCA1, MGMT and p53 which then leads to DNA damage as shown by the comet assay and quantitative real-time PCR analysis.

\section{Acknowledgements}

The present study was supported by the Taiwan Department of Health, China Medical University Hospital, Cancer Research Center of Excellence (grant no. DOH101-TD-C-111-005).

\section{References}

1. Lichtman MA: Battling the hematological malignancies: the 200 years' war. Oncologist 13: 126-138, 2008

2. Lin JP, Yang JS, Lin JJ, et al: Rutin inhibits human leukemia tumor growth in a murine xenograft model in vivo. Environ Toxicol 27: 480-484, 2012.

3. Fotoohi AK, Assaraf YG, Moshfegh A, et al: Gene expression profiling of leukemia T-cells resistant to methotrexate and 7-hydroxymethotrexate reveals alterations that preserve intracellular levels of folate and nucleotide biosynthesis. Biochem Pharmacol 77: 1410-1417, 2009.

4. Nau KC and Lewis WD: Multiple myeloma: diagnosis and treatment. Am Fam Physician 78: 853-859, 2008.

5. Nishiyama T, Matsukawa T and Hanaoka K: Intrathecal propofol has analgesic effects on inflammation-induced pain in rats. Can J Anaesth 51: 899-904, 2004.

6. de Ruijter W, Stienen GJ, van Klarenbosch J and de Lange JJ: Negative and positive inotropic effects of propofol via L-type calcium channels and the sodium-calcium exchanger in rat cardiac trabeculae. Anesthesiology 97: 1146-1155, 2002.

7. Kato R and Foex P: Myocardial protection by anesthetic agents against ischemia-reperfusion injury: an update for anesthesiologists. Can J Anaesth 49: 777-791, 2002.

8. Ko SH, Yu CW, Lee SK, et al: Propofol attenuates ischemiareperfusion injury in the isolated rat heart. Anesth Analg 85: 719-724, 1997.

9. Kokita N, Hara A, Abiko Y, Arakawa J, Hashizume H and Namiki A: Propofol improves functional and metabolic recovery in ischemic reperfused isolated rat hearts. Anesth Analg 86: 252-258, 1998.
10. Gao J, Zhao W, Xiang D and Shi Y: Effects of propofol on the expression of aquaporin-1 in lipopolysaccharide-activated rat lung microvessel endothelial cells. Chin J Critl Care Med 26: 670-672, 2006

11. Chen HI, Hsieh NK, Kao SJ and Su CF: Protective effects of propofol on acute lung injury induced by oleic acid in conscious rats. Crit Care Med 36: 1214-1221, 2008.

12. Cui WY, Tian AY and Bai T: Protective effects of propofol on endotoxemia-induced acute kidney injury in rats. Clin Exp Pharmacol Physiol 38: 747-754, 2011.

13. Wu RS, Liu KC, Tang NY, et al: cDNA microarray analysis of the gene expression of murine leukemia RAW 264.7 cells after exposure to propofol. Environ Toxicol 8: 471-478, 2011.

14. Sagara Y, Hendler S, Khoh-Reiter S, et al: Propofol hemisuccinate protects neuronal cells from oxidative injury. J Neurochem 73: 2524-2530, 1999

15. Honegger P, Pardo B and Monnet-Tschudi F: Muscimol-induced death of GABAergic neurons in rat brain aggregating cell cultures. Brain Res Dev Brain Res 105: 219-225, 1998.

16. Dallas ML, Boyle JP, Milligan CJ, et al: Carbon monoxide protects against oxidant-induced apoptosis via inhibition of Kv2.1. FASEB J 25: 1519-1530, 2011.

17. Lu CC, Yang JS, Huang AC, et al: Chrysophanol induces necrosis through the production of ROS and alteration of ATP levels in J5 human liver cancer cells. Mol Nutr Food Res 54: 967-976, 2010.

18. Chiang JH, Yang JS, Ma CY, et al: Danthron, an anthraquinone derivative, induces DNA damage and caspase cascade-mediated apoptosis in SNU-1 human gastric cancer cells through mitochondrial permeability transition pores and Bax-triggered pathways. Chem Res Toxicol 24: 20-29, 2011.

19. Liu KC, Ho HC, Huang AC, et al: Gallic acid provokes DNA damage and suppresses DNA repair gene expression in human prostate cancer PC-3 cells. Environ Toxicol: Sep 2, 2011 (Epub ahead of print). doi: 10.1002/tox.20752.

20. Kuo CL, Wu SY, Ip SW, et al: Apoptotic death in curcumintreated NPC-TW 076 human nasopharyngeal carcinoma cells is mediated through the ROS, mitochondrial depolarization and caspase-3-dependent signaling responses. Int J Oncol 39: 319-328, 2011.

21. Lu HF, Lai TY, Hsia TC, et al: Danthron induces DNA damage and inhibits DNA repair gene expressions in GBM 8401 human brain glioblastoma multiform cells. Neurochem Res 35: 1105-1110, 2010.

22. Yu FS, Yang JS, Yu CS, et al: Safrole induces apoptosis in human oral cancer HSC-3 cells. J Dent Res 90: 168-174, 2011.

23. Voso MT, D'Alo F, Greco M, et al: Epigenetic changes in therapyrelated MDS/AML. Chem Biol Interact 184: 46-49, 2010.

24. Tsuchiya M, Asada A, Arita K, et al: Induction and mechanism of apoptotic cell death by propofol in HL-60 cells. Acta Anaesthesiol Scand 46: 1068-1074, 2002.

25. Loeb KR and Loeb LA: Significance of multiple mutations in cancer. Carcinogenesis 21: 379-385, 2000.

26. Ashby J, Tinwell H, Lefevre PA and Browne MA: The single cell gel electrophoresis assay for induced DNA damage (comet assay): measurement of tail length and moment. Mutagenesis 10: 85-90, 1995.

27. Donatus IA, Sardjoko and Vermeulen NP: Cytotoxic and cytoprotective activities of curcumin. Effects on paracetamol-induced cytotoxicity, lipid peroxidation and glutathione depletion in rat hepatocytes. Biochem Pharmacol 39: 1869-1875, 1990.

28. Pool-Zobel BL, Lotzmann N, Knoll M, et al: Detection of genotoxic effects in human gastric and nasal mucosa cells isolated from biopsy samples. Environ Mol Mutagen 24: 23-45, 1994.

29. Olive PL, Banath JP and Durand RE: Detection of etoposide resistance by measuring DNA damage in individual Chinese hamster cells. J Natl Cancer Inst 82: 779-783, 1990.

30. Tice RR, Andrews PW and Singh NP: The single cell gel assay: a sensitive technique for evaluating intercellular differences in DNA damage and repair. Basic Life Sci 53: 291-301, 1990.

31. Gulcin I, Alici HA and Cesur M: Determination of in vitro antioxidant and radical scavenging activities of propofol. Chem Pharm Bull 53: 281-285, 2005.

32. Epe B: Role of endogenous oxidative DNA damage in carcinogenesis: what can we learn from repair-deficient mice? Biol Chem 383: 467-475, 2002.

33. Jiang MR, Li YC, Yang Y and Wu JR: c-Myc degradation induced by DNA damage results in apoptosis of CHO cells. Oncogene 22: 3252-3259, 2003 
34. Marnett LJ: Oxyradicals and DNA damage. Carcinogenesis 21: 361-370, 2000

35. Cimprich KA and Cortez D: ATR: an essential regulator of genome integrity. Nat Rev Mol Cell Biol 9: 616-627, 2008.

36. Liu Y and Kulesz-Martin M: p53 protein at the hub of cellular DNA damage response pathways through sequence-specific and non-sequence-specific DNA binding. Carcinogenesis 22: 851-860, 2001

37. Lou Z, Minter-Dykhouse $\mathrm{K}, \mathrm{Wu} X$ and Chen J: MDC1 is coupled to activated $\mathrm{CHK} 2$ in mammalian DNA damage response pathways. Nature 421: 957-961, 2003.

38. Choi JH, Sancar A and Lindsey-Boltz LA: The human ATR-mediated DNA damage checkpoint in a reconstituted system. Methods 48: 3-7, 2009.
39. Venkitaraman AR: Cancer susceptibility and the functions of BRCA1 and BRCA2. Cell 108: 171-182, 2002.

40. Jesien-Lewandowicz E, Jesionek-Kupnicka D, Zawlik I, et al: High incidence of $M G M T$ promoter methylation in primary glioblastomas without correlation with TP53 gene mutations. Cancer Genet Cytogenet 188: 77-82, 2009.

41. Mi J, Dziegielewski J, Bolesta E, Brautigan DL and Larner JM: Activation of DNA-PK by ionizing radiation is mediated by protein phosphatase 6. PLoS One 4: e4395, 2009.

42. Braz MG, Braz LG, Mazoti MA, et al: Lower levels of oxidative DNA damage and apoptosis in lymphocytes from patients undergoing surgery with propofol anesthesia. Environ Mol Mutagen 53: 70-77, 2012. 